\title{
Twenty Years after Leave None to Tell the Story, What Do We Now Know about the Genocide of the Tutsi In Rwanda?
}

\author{
Timothy Longman \\ Boston University; longman@bu.edu
}

\begin{abstract}
In 1999, Human Rights Watch (HRW) and the International Federation for Human Rights (FIDH) published an extensive account of genocide in Rwanda, Leave None to Tell the Story. Based on interviews and archival work conducted by a team of researchers and written primarily by Alison Des Forges, Leave None to Tell was quickly recognised as the definitive account of the 1994 genocide. In the ensuing two decades, however, much additional research has added to our understanding of the 1994 violence. In this paper, I assess Leave None to Tell the Story in light of the research conducted since its publication, focusing in particular on three major challenges to the analysis. First, research into the organisation of the genocide disputes the degree to which it was planned in advance. Second, micro-level research into the motivations of those who participated disputes the influence of ideology on the genocide. Third, research has provided increasing evidence and details of violence perpetrated by the Rwandan Patriotic Front (RPF). I contend that despite these correctives, much of the analysis continues to hold up, such as the role of national figures in promoting genocide at the local level, the impact of the dynamics of local power struggles on the violence, and the patterns of violence, including the effort after the initial massacres to implicate a wide portion of the population. Finally, as a member of the team that researched and helped write Leave None to Tell, I reflect on the value of this rare sort of research project that engages human rights organisations in an academic research project.
\end{abstract}

Keywords: Rwanda, genocide, Human Rights Watch, Alison Des Forges, local-level research

\section{Introduction}

Beginning in 1990, the small Central African country of Rwanda was shaken by a pro-democracy movement and a rebel invasion, led by exiled members of the minority Tutsi ethnic group. The government responded to the dual pressures of protest and war by offering political reforms while simultaneously seeking to regain popularity with the members of the majority Hutu group by stirring up anti-Tutsi ethnic sentiments. Both a number of new domestic human rights groups and international human rights organisations documented the regime's repression of journalists and opposition politicians and violent attacks against Tutsi. In January 1993, both Human Rights Watch (HRW) and the International Federation for Human Rights (FIDH) participated in a ten-member panel of international experts that investigated human rights abuses in Rwanda and published a devastating report that linked the government to all recent cases of anti-Tutsi ethnic violence and considered, given their nature, whether they might constitute genocide, though they suggested that the numbers killed might not reach the threshold to be labelled genocide (Fédération Internationale des Droits de l'Homme et al., 1993).

Just over a year later, of course, supporters of the Rwandan government launched a wave of violence whose status as genocide could not be disputed. In just over three months, soldiers, police, and civilian militia groups killed an estimated 80 per cent of the Tutsi then living in Rwanda. In the aftermath of this horrific violence, HRW and FIDH undertook a joint research project to explain how genocide on this magnitude could be possible just a few decades after the pledge of 'never 
again' that emerged from the Holocaust. In March 1995, a research team organised by Alison Des Forges of HRW and Eric Gillet of FIDH established an office in Rwanda and began to gather evidence, focusing both on the organisation of the genocide at the national level and on its execution at the local level, with an exploration of three local case studies. The research project that ultimately involved a dozen researchers culminated in the publication in 1999 of the 789-page report, Leave None to Tell the Story: Genocide in Rwanda, written primarily by Des Forges (1999).

Leave None to Tell the Story was quickly recognised as the definitive account of the 1994 genocide of the Tutsi, winning the Lemkin Award for the best book on genocide and becoming the go-to source for information about the genocide. Yet in the twenty years since its publication, numerous additional studies have explored Rwanda's genocide. In this paper, I revisit Leave None to Tell in light of more recent research and publications on the 1994 violence in Rwanda. I find three major areas where the analysis is challenged - the degree of planning prior to the implementation of the genocide, the motivations for participation, and the significance of violence perpetrated by the Rwandan Patriotic Front but on the whole, I contend that the analysis holds up. Finally, I argue that the production of Leave None to Tell, where human rights organisations engaged in academic research, is a model worth replicating.

\section{Key Findings in Leave None to Tell the Story}

Beginning in March 1995, a team of researchers for HRW and FIDH began collecting data about the 1994 violence in Rwanda. Des Forges took the lead in interviewing national leaders, such as military and government officials, while the research team established an office in Butare as a base for conducting local-level research. The team, which I joined in late 1995, focused on case studies of three local communities - the university town and regional capital Butare; Nyakizu, a commune south of Butare, along the Burundi border; and Musebeya, a commune in the neighbouring region of Gikongoro. We interviewed a range of individuals from each of the communities, including some in prison on genocide charges and many survivors of the genocide. We also conducted archival work, sorting through government documents in the regional office of Butare, the communal office of Nyakizu and several offices in other parts of the country to find letters, minutes from meetings and other documents related to security and violence. The bulk of this grass-roots research was completed within a year, but the book took several more years to complete, as Des Forges continued to chase down interviews and information across the globe.
Appearing five years after the genocide, in 1999, Leave None to Tell immediately became the most authoritative source for explaining the 1994 genocide of the Tutsi and to a lesser extent violence perpetrated by the Rwandan Patriotic Front (RPF). The book also became the basis for numerous prosecutions of accused genocide perpetrators. Even before publication of the text, Des Forges worked closely with prosecutors at the International Criminal Tribunal for Rwanda (ICTR), and after its publication, the book became the basis for numerous cases in Arusha. Leave None to Tell also has served as the basis for prosecutions in Canada, Belgium, France, Sweden, Finland and the United States, including cases like that of François Bazaramba in Finland that came directly out of accusations detailed in Leave None to Tell.

Since the book is technically a human rights report rather than a traditional academic tome, it begins with an executive summary that lays out the key points. In this section, I want to highlight several of the central arguments that Des Forges develops and that the majority of the text is then devoted to proving. First, Des Forges makes clear that what happened in Rwanda was in fact genocide, the targeting killing of members of the Tutsi ethnic group with the intent to destroy the group, rather than just random killing driven by popular rage: ${ }^{1}$

This genocide was not an uncontrollable outburst of rage by a people consumed by 'ancient tribal hatreds'. Nor was it the preordained result of the impersonal forces of poverty and over-population. This genocide resulted from the deliberate choice of a modern elite to foster hatred and fear to keep itself in power. This small, privileged group first set the majority against the minority to counter a growing political opposition within Rwanda. Then, faced with RPF success on the battlefield and at the negotiating table, these few powerholders transformed the strategy of ethnic division into genocide. They believed that the extermination campaign would restore the solidarity of the Hutu under their leadership and help them win the war, or at least improve their chances of negotiating a favorable peace. They seized control of the state and used its machinery and its authority to carry out the slaughter. (Des Forges, 1999: 1-2)

In this succinct passage, Des Forges wants to make clear that the killing of Tutsi in Rwanda was not a spontaneous popular uprising because of anger over the assassination of President Habyarimana or arising uncontrollably from the frustrations of overpopulation and poverty. Instead the killing was a systematic slaughter that was planned and executed from above by leaders intent on protecting their own power. The role of elites in organising the genocide and their use of the state to carry out the violence are central points that she spends much of the first half of the book detailing. 
Most of the killing, however, was carried out by average Rwandans, and explaining their motivations is another of Des Forges' primary goals:

Hundreds of thousands of others chose to participate in the genocide reluctantly, some only under duress or in fear of their own lives. Unlike the zealots who never questioned their original choice, these people had to decide repeatedly whether or not to participate, each time weighing the kind of action planned, the identity of the proposed victim, the rewards of participating and the likely costs of not participating. Because attacks were incited or ordered by supposedly legitimate authorities, those with misgivings found it easier to commit crimes and to believe or pretend to believe they had done no wrong. (p. 2)

The case studies of Butare, Nyakizu and Musebeya (and other parts of Gikongoro) that occupy the second half of the book explore the dynamics of local involvement. They seek to explain exactly how national, regional and local elites exercised their authority to convince individuals and communities to participate in the killing. The main point is that, left to their own devices, average Rwandans would generally not have killed. To get people to participate took regular and repeated intervention from individuals with authority. These elites used ideological justifications, incentives and threats to inspire participation. In many cases, local leaders themselves resisted instigating the violence, requiring national organisers of the genocide to pressure leaders with incentives and threats and ultimately to remove those who posed an impediment to the violence.

Another central point in Leave None to Tell is that the international community made a deliberate decision to allow the genocide in Rwanda to take place. The genocide of the Tutsi was never inevitable, it was foreseen, and it could have been stopped. In contrast to authors like Mahmood Mamdani, who argues that the Rwandan genocide was rooted in Rwanda's colonial history (Mamdani, 2001), Des Forges, although an historian herself, insists that the genocide was not built into the fabric of Rwandan history but was instead a conscious political strategy undertaken by a modern elite. Because the genocide was a well-developed plan, it could have been prevented and, even after it began, it could have been stopped.

Policymakers in France, Belgium, and the United States and at the United Nations all knew of the preparations for massive slaughter and failed to take the steps needed to prevent it. Aware from the start that Tutsi were being targeted for elimination, the leading foreign actors refused to acknowledge the genocide.... When international leaders did finally voice disapproval, the genocidal authorities listened well enough to change their tactics although not their ultimate goal. Far from cause for satisfaction, this small success only underscores the tragedy: if timid protests produced this result in late April, what might have been the result in mid-April had all the world cried 'Never again'. (p. 2)

One chapter of the text is devoted to a chronological accounting of all of the warning signs that indicated to internal and international observers the preparations that were underway for genocide. The penultimate section of the book outlines the failed response of the international community, particularly the United Nations, which had a mission on the ground in Rwanda.

The thread that runs through the text and ties these three main points together is the idea that the genocide was a conscious choice. The genocide was neither accidental nor an inevitable result of history or culture or demographics. Instead, the genocide was a statesponsored programme deliberately chosen by a group of political, military and business leaders who saw the violence as a means of preserving their power in the face of growing threats. This group orchestrated the violence and determined that Tutsi were to be its primary targets. They gave orders to their political subordinates to organise the violence at the local level, and they deployed their armed forces to help spread the violence. Not all national leaders approved of the genocide; a few actively sought to hinder the violence, while many others simply went along without actively supporting. At every level of society, individuals had to choose how to respond to the calls to participate in the killing, and even once individuals had participated, they had to choose to continue their participation on a daily basis. Likewise, Des Forges makes clear that the international community also made deliberate choices to allow the violence in Rwanda to continue unabated. She shows conclusively that claims to ignorance about what was happening in Rwanda were false.

A final point in the text that does not figure into the initial brief summary at the beginning of the book and remains somewhat peripheral to the overall argument, though it is discussed in the introduction, is to highlight violence perpetrated against civilians by the RPF:

In defeating the interim government and its army, the RPF ended the genocide. At the same time, its troops committed grave violations of international humanitarian law by attacking and killing unarmed civilians.... The RPF permitted its soldiers to kill persons whom they took to be Interahamwe or other supposed participants in the genocide. They killed some in the course of their military advance, but they executed most in the days and weeks after combat had finished. They selected the victims from among civilians grouped in camps, sometimes relying on accusations by survivors, sometimes on their own interrogations. They executed some persons apparently because 
they were linked with parties opposed to the RPF or showed potential for becoming political leaders rather than because they were thought guilty of involvement in the genocide. (p. 16)

In contrast to the violence that was part of the genocide, RPF violence was less systematic and, because it was not aimed at a particular ethnic group with the intent of destroying it, does not constitute genocide. At the same time, RPF violence was not simply the action of rogue soldiers but involved both summary judgment of those believed to be implicated by the genocide and attempts to assert control by eliminating individuals who could threaten RPF power. While the RPF violence was not genocide, it did represent 'grave violations of international humanitarian law'.

\section{Assessing the Argument Twenty Years On}

Over the past twenty years, numerous additional publications focusing on the genocide of the Tutsi in Rwanda and related violence in 1994 have appeared, but in general, the arguments and analysis in Leave None to Tell have held up well. As René Lemarchand stated in a recent review of the state of the literature on the genocide, 'The story of Rwanda's agonies has been told many times in many forms, but nowhere more persuasively than in Alison Des Forges' landmark investigation, Leave No One To Tell the Story. It remains the most wide-ranging, thoroughly researched and reliable source of information on the 1994 genocide' (Lemarchand, 2013).

Many of the works published since 1999 have gone into greater depth on specific issues that are covered in Leave None to Tell and offer detail without contradicting the basic arguments. For example, several works have looked in greater depth at sexual and gender-based violence in the genocide. In Sacrifice as Terror, Christopher Taylor explores the logic of sexual violence within Rwandan cultural conceptions of Tutsi beauty and seductiveness (Taylor, 1999). Both Jennie Burnet's Genocide Lives in Us and Marie Berry's War, Women, and Power are focused primarily on women in postgenocide Rwanda, but both nevertheless provide greater detail on the experience of women in the genocide that remains consistent with Des Forges' analysis (Berry, 2018; Burnet, 2013). In a series of publications, Philip Verwimp applies the tools of economics to understanding not just the causes of the genocide but such problems as the level of mortality and testing the theory of double genocide (Verwimp, 2003, 2013). My own book, Christianity and Genocide in Rwanda, looks in detail at the role of Christian churches in the violence (Longman, 2010).
Others provide detail on specific cases. In Rwanda 1994: Les Politiques du Génocide à Butare, André Guichaoua draws on the research that he compiled for his testimony at the ICTR to discuss in depth the conduct of the genocide in the city of Butare, adding details to the description provided in the chapters on Butare in Leave None to Tell (Guichaoua, 2005). Jean-Paul Kimonyo's Rwanda's Popular Genocide explores how the genocide was carried out in several additional local communities based on his own original research, including adding additional detail on Butare (Kimonyo, 2016). Still others provide greater detail on the failures of international intervention. Michael Barnett provides insight into the UN's failures based on his perspective working in New York at the time (Barnett, 2003), while Romeo Dallaire's memoir Shake Hands with the Devil, gives a searing account of the genocide from the perspective of the commander of the UN contingent (Dallaire, 2003). A range of other non-scholarly texts, both memoirs and collections of testimonies, flesh out the human experience of the genocide.

Rather than giving a comprehensive account of everything published on the genocide since 1999, I want to turn to three specific issues where research has challenged - sometimes in subtle ways - Des Forges' conclusions in Leave None to Tell.

\section{Questions of Planning}

As in his previous book on Butare, in From War to Genocide: Criminal Politics in Rwanda, 1990-1994, André Guichaoua (2015) draws on his research for testifying at the ICTR, this time focusing on the execution of the genocide at the national level for trials of military and government officials. His account provides greater detail about the figures at the centre of power and how they came to carry out the systematic slaughter of Rwanda's Tutsi population and Hutu critics of the regime. In contrast to most previous authors, including Des Forges, Guichaoua contends that the leaders who took over after Habyarimana's death did not have a clear plan for the full-scale genocide in advance. A loosely connected group of powerful individuals, primarily from Habyarimana's home region in the north, many with close connections to President Habyarimana's wife, had acted over the previous two years to consolidate their power in the face of expanding opposition. They promoted an antiTutsi ideology that treated Tutsi as sub-human, alien interlopers who should be expelled or eliminated from Rwanda. They had developed a network of supporters throughout the country known as Hutu Power, built a security infrastructure, handed out weapons, and trained militia groups, so the tools that they needed to carry out genocide were in place. 
But according to Guichaoua's research, there was not a well-developed, specific plan to carry out genocide. In fact, in the aftermath of Habyarimana's assassination, there was a power struggle among various national leaders. One group used the president's death as an opportunity to launch an attack on people they saw as the primary threats to their power - opposition politicians, journalists and civil society activists, a large portion of whom were Tutsi. After a couple of days, the violence paused, as more moderate elements sought to stop its spread. But as the international community made clear that it would take no action against the country, more extremist elements used the spread of the violence to consolidate their positions. They then spread the killing systematically through the country and made it more specifically focused on Tutsi.

In other words, Guichaoua is arguing that rather than being the result of a careful master plan, Rwanda stumbled into genocide, as the strategy of asserting power by exterminating the Tutsi developed even as it was being implemented. The discussion carries echoes of the debate between intentionalists and structuralists in Holocaust studies, a disagreement over whether the genocide of Jews was the direct result of a master plan or grew out of the logic and structures of the Nazi state (Mason, 1981: 21-40; Browning, 2004). I discussed this issue with Des Forges shortly before her death, and she was inclined to agree with Guichaoua's perspective, though in practice it makes the intentionality required to demonstrate genocide somewhat more difficult to prove in court. What Guichaoua argues does not make what happened in Rwanda any less a genocide, because the goal was to wipe out Rwanda's Tutsi, even if this goal developed as part of a strategy to consolidate political power. In fact, the idea that the genocide was not mapped out in advance reinforces the reality that the violence was not inevitable and could have been halted with effective international action.

\section{Ideology and the Motives of Those Who Killed}

Many of the early studies of the genocide put major emphasis on the role of ideology in driving people to participate. Several works focused specifically on proregime newspapers and radio that were labelled 'hate media' and their diffusion of anti-Tutsi rhetoric (Chrétien, 1995; Thompson, 2007). Drawing parallels to the anti-Semitic ideology tied to the Holocaust, the argument was that the ideology dehumanised the Tutsi, alienated them from the rest of the population, and fostered hatred that ultimately drove people to kill. Leave None to Tell includes a chapter on 'Propaganda and Practice', that explores the anti-Tutsi ideology and a series of massacres from 1990 to 1993 in which the application of this ideology to violence was tested.
Throughout the text, there is emphasis on the coded language used to instigate participation, as Tutsi are referred to as 'snakes' and killing is euphemistically described as 'work' and 'cutting tall trees'.

Subsequent research on the motivations of people who participated in the genocide has challenged the centrality of ideology as a key stimulus for violence. Two important texts in particular have suggested that most people did not kill out of hatred of the Tutsi but rather for a variety of other reasons. In Killing Neighbors, the late Lee Ann Fujii looked at the ways in which social networks drew individuals into participating in the killing in two local communities, one in Rwanda's north, the other in the centre of the country. She argues that ethnic difference was not itself the cause of the violence but was a tool used by elites to divide the population and that local-level group dynamics influenced people to participate. She labels those who killed 'joiners', because they were motivated not primarily by a desire to kill Tutsi but by a desire to be fully part of the group that was taking part in the killing (Fujii, 2009).

Based on interviews with dozens of confessed killers, Scott Straus also challenges the idea that hatred drove the genocide. In The Order of Genocide, Straus argues that fear was the primary factor motivating people to join in the killing. The government organising the genocide controlled access to information and claimed that the RPF was killing all Hutu it encountered and that Tutsi within Rwanda were RPF agents. As the war spread and RPF fighting drove displaced people across the country, government claims that participating in violence was necessary for defensive reasons made sense. More importantly, though, the fact that the violence was being ordered by the state and that people who resisted could be fined, beaten or even killed, filled people with another kind of fear that interacted with and built on the first and drove participation (Straus, 2008). In another piece, Straus further challenges the role of ideology by demonstrating convincingly that the 'hate radio' station RTLM had a much smaller reach than has been generally understood. Since RTLM actually only broadcast within a very small range, it could not have played the major role in instigating killing that many have claimed (Straus, 2007).

In challenging the idea that ideology drove the genocide and complicating our understanding of motivations, these works are not necessarily directly contradicting Leave None to Tell but instead pushing its argument and adding to the understanding of why people killed. In my own work on the churches and the genocide, I explore the issue of motivations somewhat differently. In looking at the influence of Christianity, I suggest that church teaching did not exactly encourage people to hate Tutsi but instead justified their exclusion 
and ultimately made killing them morally acceptable. I agree with Fujii and Straus that most people did not kill out of hatred but I do suggest that the ideology had a couple of important roles. First, it helped to create a clear line between Hutu and Tutsi, which identified Tutsi as a distinct group to be excluded and targeted. Second, I contend that the ideology did in fact influence many of the elite who had seen their monopoly on power increasingly challenged in recent years. Some of the elite I knew in the period prior to the genocide seemed to sincerely hate the Tutsi, blaming them for attacking the country and exploiting its population (Longman, 2010).

\section{RPF Violence}

A final area where scholarship has challenged the argument in Leave None to Tell is one that Des Forges herself embraced fully in subsequent years: the involvement of the RPF in violence against civilians. We have gained considerable information about RPF violence in the Democratic Republic of Congo in the 1996-97 and 1998-2003 wars (Umutesi, 2000; Bradol and Le Pape, $2017)^{2}$ but that violence falls outside the timeframe considered by Leave None to Tell. Similarly, numerous recent works have explored the violent and authoritarian nature of RPF rule since 1994 (Reyntjens, 2013). ${ }^{3}$ Not much additional data has appeared regarding RPF violence from 1990-94. An insider account by RPF dissident Abdul Ruzibiza both accuses Kagame of organising the assassination of Habyarimana and argues that massacres of Hutu were intentional rather than random (Ruzibiza, 2005). Journalist Judi Rever's recent book, In Praise of Blood, is quite sensationalistic in accusing the RPF of crimes against humanity, including genocide, but it provides only limited new information about RPF abuses within Rwanda. It does provide more detail about several instances discussed by Des Forges, such as massacres in RPF-occupied Byumba (Rever, 2018). No academic has yet written a well-researched and detailed account of RPF violence, most likely because doing the necessary research would be both prohibitively difficult and extremely dangerous (Rever, 2018; Santoro, 2015). ${ }^{4}$

In reality, the chapter on RPF abuses in Leave None to Tell already contains quite detailed discussion of RPF massacres and summary executions. Des Forges both discusses patterns of RPF violence and also documents a number of specific attacks. What has changed since 1999, then, is less the data about RPF abuses than their framing. In Leave None to Tell, Des Forges treats the RPF violence as serious but also rather incidental to the key story, which is the genocide. In subsequent years, however, it became increasingly clear that even as extensive efforts were made to hold genocide perpetrators accountable, RPF officials involved in war crimes and crimes against humanity would face no consequences. Although the ICTR was authorised to include RPF crimes within its consideration, the ICTR brought no charges against RPF officials. In fact, when Chief Prosecutor Carla Del Ponte attempted to launch investigations into RPF crimes, the RPF used its influence to have the tribunal reorganised and a new prosecutor appointed. In the last several years before her death, Des Forges increasingly highlighted the significance of RPF crimes and the need for accountability in order to avoid the appearance of victors' justice.

\section{Leave None to Tell as a Research Model}

The research project that produced Leave None to Tell the Story was a unique undertaking. While organised by human rights organisations, the project employed a number of academic researchers and produced a report that is closer to an academic text than a traditional human rights report. Des Forges herself had a PhD in history, as did Michele Wagner and Christine Deslaurier, while I was trained in political science and Catherine Choquet worked at the University of Paris 1. Kirsti Lattu and Trish Hiddleston had backgrounds in humanitarian work. Only Eric Gillet and Lynn Welchman had backgrounds as human rights lawyers, the more typical qualification for a human rights researcher.

In closing, I want to suggest that this cooperative project between academics and human rights organisations was a highly beneficial endeavour that should be a model for future collaborations. Research done by groups like HRW and Amnesty International ordinarily falls somewhere between journalism and academic research. While journalists are generally looking for things that make a good story, particularly the extraordinary, human rights researchers are more interested in patterns of abuse, avoiding focus on one-time incidents or actions outside the ordinary. In my experience researching and writing reports for HRW, emphasis is placed on gathering eyewitness accounts and ensuring that published claims are always based on more than one account. HRW, FIDH and Amnesty do not have institutional research boards, but in training for researchers, emphasis is placed on protection of sources and the legal office carefully vets reports to ensure that claims are supported by evidence sufficiently to be able to stand up in court.

Academic research differs from research by human rights organisations in some subtle ways. Human rights organisations like journalists are focused on timeliness, seeking to expose unknown stories about events currently underway and make news. Academic researchers tend to be more interested in understanding events in new ways and in taking the time to pursue hidden facts 
even if it means that a story may be delayed. It is not that human rights researchers are in any way careless - in fact, the reputation of their organisations requires that they not be - but expedience is more important than thoroughness. If additional facts need to be uncovered, the preference is generally to go ahead in a timely manner with the claims that can be substantiated and to include additional details in subsequent reports.

In the case of Leave None to Tell, HRW hoped that it would be published in 1996, and they were deeply frustrated that Des Forges continued to research and refine the text for several more years. ${ }^{5}$ Yet what was sacrificed in terms of expediency was gained in terms of precision and thoroughness. Des Forges literally spent years chasing down details, seeking out witnesses and documentation in order to complete the story of the genocide. The resulting document had an impact different than that of a traditional human rights report, but its impact has been profound, particularly on increasing accountability for the genocide.

I know of no comparable projects that brought academics actively into human rights organisation research, but I believe that the precedent set by the Rwandan genocide research project sponsored by HRW and FIDH deserves to be replicated in other contexts. Human rights organisations not only focus on exposing human rights abuses but also on seeking accountability for those abuses. While less expedient, the type of research that academics conduct can provide the detail and documentation needed to more effectively prosecute cases against perpetrators of mass atrocities. The interaction between human rights lawyers and academic researchers is productive for both communities, as it forces academics to think in practical, real-world terms. Although the brilliance of Leave None to Tell the Story is due in large part to the personal brilliance of Alison Des Forges, something that is impossible to replicate, human rights groups can nevertheless effectively draw on scholars with deep knowledge of specific countries and their histories in ways that will enrich human rights work and expand the impact of their organisations.

\section{Notes}

1 According to the 1948 Convention on the Prevention and Punishment of the Crime of Genocide, genocide is defined as 'acts committed with intent to destroy, in whole or in part, a national, ethnical, racial or religious group, as such: a. Killing members of the group; b. Causing serious bodily or mental harm to members of the group; ....'

2 Umutesi was initially the most influential. The UN investigative report mapping human rights violations in Congo released in 2010 provided details and proof of massive human rights violation in Eastern Congo. Office of the High Commissioner of Human Rights, 'Democratic Republic of Congo, 1993-2003: Report of the Mapping Exercise documenting the most serious violations of human rights and international humanitarian law committed within the territory of the Democratic Republic of the Congo between March 1993 and June 2003', Geneva: OHCHR, August 2010, www.ohchr.org/ Documents/Countries/CD/DRC_MAPPING_REPORT_ FINAL_EN.pdf (accessed 21 February 2019).

3 Most notable is Reyntjens (2013) who provides a detailed chronicle of abuses of power by the RPF, including human rights abuses.

4 Rever herself faced threats to herself and her family in Europe and Canada traced to Rwandan forces.

5 This claim is based on my own conversations with HRW officials during my time working for them.

\section{Bibliography}

Barnett, M. (2003), Eyewitness to Genocide: The United Nations and Rwanda (Ithaca, NY: Cornell University Press).

Berry, M. E. (2018), War, Women, and Power: From Violence to Mobilization in Rwanda and Bosnia-Herzegovina (Cambridge: Cambridge University Press).

Bradol, J-H. and Le Pape, M. (2017), Humanitarian Aid, Genocide and Mass Killings: Médecins Sans Frontières, the Rwandan Experience, 1982-97 (Manchester: Manchester University Press).

Browning, C. R. (2004), The Origins of the Final Solution: The Evolution of Nazi Jewish Policy, September 1939-March 1942 (Lincoln: University of Nebraska Press).

Burnet, J. E. (2013), Genocide Lives in Us: Women, Memory, and Silence in Rwanda (Madison: University of Wisconsin Press).

Chrétien, J-P. (ed.) (1995), Rwanda: Les médias du génocide (Paris: Karthala).

Dallaire, R. (2003), Shake Hands with the Devil: The Failure of Humanity in Rwanda (New York: Random House).

Des Forges, A. (1999) Leave None to Tell the Story: Genocide in Rwanda (New York: Human Rights Watch and Paris: FIDH).

Fédération Internationale des Droits de l'Homme, Africa Watch et al. (1993), 'Rapport de la Commission Internationale d'Enquête sur les Violations des Droits de l'homme au Rwanda depuis le ler Octobre 1990 (7-21 janvier 1993)' (Paris: FIDH).

Fujii, L. A. (2009), Killing Neighbors: Webs of Violence in Rwanda (Ithaca, NY: Cornell University Press).

Guichaoua, A. (2005), Rwanda 1994: Les Politiques du Génocide à Butare (Paris: Karthala).

Guichaoua, A. (2015), From War to Genocide: Criminal Politics in Rwanda 1990-1994 (Madison: University of Wisconsin Press).

Kimonyo, J-P. (2016), Rwanda's Popular Genocide: A Perfect Storm (Boulder, CO: Lynne Rienner).

Lemarchand, R. ([2013] 2018), 'Rwanda: The State of Research', originally published May 27, 2013, revised edition published 25 June 2018. www.sciencespo.fr/mass-violence-war-massacre-resistance/en/ document/rwanda-state-research (accessed 15 February 2019).

Longman, T. (2010), Christianity and Genocide in Rwanda (New York: Cambridge University Press).

Mamdani, M. (2001), When Victims Become Killers: Colonialism, Nativism and the Genocide in Rwanda (Princeton, NJ: Princeton University Press).

Mason, T. (1981), 'Intention and explanation: A current controversy about the interpretation of National Socialism', in Hirschfeld, G. and Kettenacker, L. (eds), Der 'Führerstaat': Mythos und Realität (Stuttgart: Klett-Cotta), pp. 21-40. 
Rever, J. (2018), In Praise of Blood: The Crimes of the Rwandan Patriotic Front (Toronto: Random House Canada).

Reyntjens, F. (2013), Political Governance in Post-Genocide Rwanda (New York: Cambridge University Press).

Ruzibiza, A. J. (2005), Rwanda: L'histoire secrète (Paris: Editions du Panama).

Santoro, L. (2015), 'Terror as Method: A Journalist's Search for Truth in Rwanda', Foreign Policy Journal, 25 September. www.foreignpolicyjournal.com/2015/09/25/terror-as-method-a-journalists-searchfor-truth-in-rwanda/\#comments (accessed 22 February 2019).

Straus, S. (2007), 'What is the Relationship between Hate Radio and Violence? Reexamining Rwanda's "Radio Machete", Politics \& Society, 35:4, 609-37.
Straus, S. (2008), The Order of Genocide: Race, Power, and War in Rwanda (Ithaca, NY: Cornell University Press).

Taylor, C. C. (1999), Sacrifice as Terror: The Rwandan Genocide of 1994 (New York: Berg).

Thompson, A. (ed.) (2007), The Media and the Rwanda Genocide (London: Pluto Press).

Umutesi, M. B. (2000), Fuir ou mourir au Zaïre. Le vécu d'une réfugiée rwandaise (Paris: L'Harmattan).

Verwimp, P. (2003), 'Testing the Double Genocide Thesis for Central and Southern Rwanda', Journal of Conflict Resolution, 47:4, 423-42.

Verwimp, P. (2013), Peasants in Power: The Political Economy of Development and Genocide in Rwanda (Dordrect: Springer). 